\title{
PENGEMBANGAN SDM UNTUK MENINGKATKAN KINERJA TERKAIT KESELAMATAN KERJA (STUDI KASUS DI PT. XYZ)
}

\author{
Gun Nanda Tian Purnama ${ }^{1}$, Zulfa Fitri Ikatrinasari ${ }^{2}$ \\ ${ }^{1}$ Magister Teknik Industri, Fakultas Teknik, Universitas Mercu Buana, \\ gun.nanda.tp@gmail.com \\ ${ }^{2}$ Magister Teknik Industri, Fakultas Teknik, Universitas Mercu Buana, zulfafitri@gmail.com
}

\begin{abstract}
The Human Resource Development (HR) section has the task and responsibility in developing personal personalities and organizational skills. Each organization will strive to achieve the goals of the organization. Work accidents are unplanned, uncontrolled, and unexpected things that interfere with work effectiveness. The causes of occupational injuries are divided into five, namely the factors man, machine, material, method, and environment. An effective workplace accident prevention requires the proper execution of work by everyone at work. All workers must be aware of the hazards of the materials and equipment they are handling, all the dangers of the company's operations and the way they are controlled. This requires training to improve workers' knowledge on occupational safety and health. The achievement of Key Performance Indicator (KPI) performance related to safety is from the value of Frequency Rate (FR) and Safe-T Score. Both KPIs are indicators in the assessment of safety performance in the company. The result of the implementation of the human resource development program is the decline of FR KPI value from 2.29 in the period 2015-2016 to 0.91 in the period of 2017, it shows that the potential for work accidents is getting smaller. In the KPI Safe-T Score obtained value -1.35 this shows that there has been a change in company performance related to safety work after the implementation of the program.
\end{abstract}

Keywords: Human Resources, Work Accidents, Knowledge, Frequency Rate (FR) and Safe-T Score.

\begin{abstract}
ABSTRAK
Bagian pengembangan Sumber Daya Manusia (SDM) memiliki tugas dan tanggung jawab dalam mengembangkan kepribadian personal dan keterampilan organisasional. Setiap organisasi akan berupaya dapat tercapainya tujuan organisasi. Kecelakaan kerja adalah sesuatu yang tidak terencana, tidak terkontrol, dan sesuatu hal yang tidak diperkirakan sebelumnya sehingga mengganggu efektivitas kerja. Penyebab kecelakaan kerja dibagi menjadi lima, yaitu faktor man, machine, material, method, dan environment. Suatu pencegahan kecelakaan kerja yang efektif memerlukan pelaksanaan pekerjaan dengan baik oleh setiap orang ditempat kerja. Semua pekerja harus mengetahui bahaya dari bahan dan peralatan yang mereka tangani, semua bahaya dari operasi perusahaan serta cara pengendaliannya. Untuk itu diperlukan pelatihan untuk meningkatkan pengetahuan pekerja mengenai keselamatan dan kesehatan kerja. Pencapaian kinerja Key Performance Indicator (KPI) terkait keselamatan kerja yaitu dari nilai Frequency Rate (FR) dan Safe-T Score. Kedua KPI tersebut merupakan indikator dalam penilaian kinerja keselamatan kerja yang ada di perusahaan. Hasil penerapan program pengembangan SDM tersebut adalah penurunan nilai KPI FR dari 2.29 pada periode $2015-2016$ menjadi 0.91 pada periode 2017 , hal
\end{abstract}


ini menunjukan bahwa potensi terjadinya kecelakaan kerja semakin kecil. Pada KPI Safe-T Score diperoleh nilai -1.35 hal ini menunjukan telah terjadi perubahan kinerja perusahaan terkait keselamatan kerja setelah penerapan program.

Kata kunci: Sumber Daya Manusia, Kecelakaan Kerja, Pengetahuan, Frequency Rate (FR) dan Safe-T Score.

\section{PENDAHULUAN}

Setiap perusahaan pasti memiliki bagian pengembangan Sumber Daya Manusia (SDM) dalam struktur organisasinya. Bagian pengembangan SDM pada dasarnya memiliki tugas dan tanggung jawab untuk membantu karyawan dalam mengembangkan kepribadian personal dan keterampilan organisasional mereka. Pengembangan SDM adalah sebuah rangkaian aktivitas perusahaan yang dilakukan dalam waktu tertentu dan dirancang untuk melahirkan perubahan sikap karyawan (Nadler, 1990).

Setiap organisasi apapun bentuknya senantiasa akan berupaya dapat tercapainya tujuan organisasi. Ini berarti bahwa sumber daya manusia yang ada dalam organisasi tersebut secara proporsional harus diberikan latihan dan pendidikan yang sebaik-baiknya, bahkan harus sesempurna mungkin. Pengembangan karyawan bertujuan dan bermanfaat bagi perusahaan, karyawan, konsumen, atau masyarakat yang mengkonsumsi barang/jasa yang dihasilkan perusahaan. Tujuan pengembangan adalah (Tohardi, 2008) :

1. Produktivitas. Dengan pengembangan, produktivitas kerja karyawan akan meningkat, kualitas dan kuantitas produksi akan semakin baik, karena technical skill, human skill dan managerial skill karyawan akan semakin baik.

2. Efisiensi. Pengembangan karyawan untuk meningkatkan efisiensi sumber daya manusia, waktu, bahan baku dan mengurangi ausnya mesin-mesin. Pemborosan berkurang, biaya produksi relatif kecil sehingga daya saing perusahaan semakin kecil.

3. Kerusakan. Pengembangan karyawan bertujuan untuk mengurangi kerusakan barang, produksi dan mesin-mesin karena karyawan semakin ahli dan terampil dalam melaksanakan pekerjaannya.

4. Kecelakaan. Pengembangan bertujuan untuk mengurangi tingkat kecelakaan karyawan, sehingga jumlah biaya pengobatan yang keluarkan perusahaan berkurang.

5. Pelayanan. Pengembangan bertujuan untuk meningkatkan pelayanan yang lebih baik dari karyawan kepada nasabah perusahaan, karena pemberian pelayanan yang lebih baik merupakan daya penarik yang sangat penting bagi rekanan-rekanan perusahaan bersangkutan.

6. Moral. Dengan pengembangan, moral karyawan akan lebih baik karena keahlian dan keterampilannya sesuai dengan pekerjaannya sehingga merek antusias menyelesaikan pekerjaannya dengan baik.

7. Karier. Dengan pengembangan, kesempatan untuk meningkatkan karier karyawan semakin besar, karena keahlian, keterampilan dan prestasi kerjanya lebih baik, promosi ilmiah biasanya didasarkan kepada keahlian dan prestasi kerja seseorang.

8. Konseptual. Dengan pengembangan, manajer akan semakin cakap dan cepat dalam mengambil keputusan yang lebih baik, karena technical skill, human skill dan managerial skill nya lebih baik.

9. Kepemimpinan. Dengan pengembangan, kepemimpinan seorang manajer akan lebih baik, human relationsnya lebih luas, motivasi lebih terarah sehingga pembinaan kerja sama vertikal dan horizontal semakin harmonis.

10. Balas Jasa. Dengan pengembangan, balas jasa (gaji, upah, intensif dan benefit) karyawan akan meningkat karena prestasi kerja mereka semakin besar. 
11. Konsumen. Pengembangan karyawan akan memberikan manfaat yang lebih baik bagi masyarakat konsumen karena mereka akan memperoleh barang atau pelayanan yang lebih bermutu.

Bentuk pengembangan dikelompokkan atas; Pengembangan secara informal,dan pengembangan secara formal (Hasibuan, 2008). Untuk lebih jelasnya kedua jenis pengembangan di atas dapat diuraikan sebagai berikut :

1. Pengembangan secara informal : Pengembangan secara informal yaitu karyawan atas keinginan dan usaha sendiri melatih dan mengembangkan dirinya dengan mempelajari buku-buku literatur yang ada hubungannya dengan pekerjaan atau jabatannya. Pengembangan secara informal menunjukkan bahwa karyawan tersebut berkeinginan keras untuk maju dengan cara meningkatkan kemampuan kerjanya. Hal ini bermanfaat bagi perusahaan karena produktivitas kerja karyawan semakin besar, di samping efisiensi dan produktivitasnya juga semakin baik.

2. Pengembangan secara formal : Pengembangan secara formal yaitu karyawan ditugaskan perusahaan untuk mengikuti pendidikan atau latihan, baik yang dilakukan perusahaan maupun yang dilaksanakan oleh lembaga-lembaga pendidikan atau pelatihan. Pengembangan secara formal dilakukan di perusahaan karena tuntutan pekerjaan saat ini ataupun masa datang, sifatnya non karier atau peningkatan karier seorang karyawan.

Kecelakaan kerja adalah sesuatu yang tidak terencana, tidak terkontrol, dan sesuatu hal yang tidak diperkirakan sebelumnya sehingga mengganggu efektivitas kerja seseorang (Anton, 1989). Penyebab kecelakaan kerja dibagi menjadi lima, yaitu faktor man, machine, material, method, dan environment.

Sistem Manajemen Keselamatan dan Kesehatan Kerja yang selanjutnya disingkat SMK3 adalah bagian dari sistem manajemen perusahaan secara keseluruhan dalam rangka pengendalian risiko yang berkaitan dengan kegiatan kerja guna terciptanya tempat kerja yang aman, efisien dan produktif (PP 50, 2012).

Suatu pencegahan kecelakaan kerja yang efektif memerlukan pelaksanaan pekerjaan dengan baik oleh setiap orang ditempat kerja. Semua pekerja harus mengetahui bahaya dari bahan dan peralatan yang mereka tangani, semua bahaya dari operasi perusahaan serta cara pengendaliannya. Untuk itu diperlukan pelatihan untuk meningkatkan pengetahuan pekerja mengenai keselamatan dan kesehatan kerja atau dijadikan satu paket dengan pelatihan lain. Berbagai cara yang umum digunakan untuk meningkatkan keselamatan kerja bidang industri dewasa ini diklasifikasikan sebagai berikut (ILO, 1989) :

1. Peraturan

Peraturan merupakan ketentuan yang harus dipatuhi mengenai hal-hal yang seperti kondisi kerja umum, perancangan, kontruksi, pemeliharaan, pengawasan, pengujian dan pengoperasian peralatan industri, kewajiban para pengusaha dan pekerja, pelatihan, pengawasan kesehatan, pertolongan pertama, dan pemeriksaan kesehatan.

2. Standarisasi

Yaitu menetapkan standar resmi, setengah resmi, ataupun tidak resmi, misalnya mengenai konstruksi yang aman dari jenis peralatan industri tertentu seperti penggunaan alat keselamatan kerja, kebiasaan yang aman dan sehat, ataupun tentang alat pengaman perorangan.

3. Pengawasan

Untuk meningkatkan keselamatan kerja perlu dilakukan pengawasan yang berupa usaha penegakan peraturan yang harus dipatuhi. Hal ini dilakukan supaya peraturan yang ada benar-benar dipatuhi atau tidak dilanggar, sehingga apa yang menjadi sasaran maupun tujuan dari peraturan keselamatan kerja dapat tercapai. 
Jurnal Inkofar * Volume 1 No. 1, Juli 2018 * ISSN: 2615-3645 (Print) / 2581-2920 (Online)

Tersedia secara online di: http://www.politeknikmeta.ac.id/meta/ojs/

Bagi yang melanggar peraturan tersebut sebaiknya diberikan sanksi atau punishment.

4. Riset Teknis

Hal yang termasuk dalam riset teknis berupa penyelidikan peralatan dan ciri-ciri dari bahan berbahaya, penelitian tentang perlindungan mesin, pengujian masker pernafasan, dan sebagainya. Riset ini merupakan cara paling efektif yang dapat menekan angka kejadian kecelakaan kerja maupun penyakit akibat kerja.

5. Riset medis

Termasuk penyelidikan dampak fisiologis dan patologis dari faktor lingkungan dan teknologi, serta kondisi fisik yang amat merangsang terjadinya kecelakaan. Setelah diketahui faktor yang berpengaruh terhadap terjadinya kecelakaan, maka seseorang dapat menghindari dan lebih berhati-hati dengan potensi bahaya yang ada.

6. Riset Psikologis

Sebagai contoh adalah penyelidikan pola psikologis yang dapat menyebabkan kecelakaan. Psikologis seseorang sangat membawa pengaruh besar dengan kecelakaan. Karena apa yang dirasakan/sedang dialami cenderung terus menerus berada dalam pikiran, hal inilah yang dapat mempengaruhi konsentrasi saat bekerja sehingga adanya bahaya kadang terabaikan.

7. Riset Statistik

Digunakan untuk mengetahui jenis kecelakaan yang terjadi, berapa banyak, kepada tipe orang yang bagaimana yang menjadi korban, dalam kegiatan seperti apa, dan apa saja yang menjadi penyebabnya. Riset seperti ini dapat dijadikan sebagai pelajaran atau acuan agar dapat terhidar dari kecelakaan, kerena belajar dari pengalaman yang terdahulu.

8. Pendidikan

Hal ini meliputi pengajaran subyek keselamatan sebagai mata ajaran dalam akademi teknik, sekolah dagang ataupun kursus magang. Pemberian pendidikan mengenai keselamatan dan kesehatan kerja pada usia sekolah diharapkan sebelum siswa terjun ke dunia kerja sudah memiliki bekal terlebih dahulu tentang bagaimana cara dan sikap kerja yang yang aman dan selamat, sehingga ketika terjun ke dunia kerja mereka mampu menghindari potensi bahaya yang dapat menyebabkan celaka.

9. Pelatihan

Salah satu contoh pelatihan yaitu berupa pemberian instruksi praktis bagi para pekerja, khususnya bagi pekerja baru dalam hal keselamatan kerja. Perlunya pemberian pelatihan karena pekerja baru cenderung belum mengetahui hal-hal yang ada di perusahaan yang baru ditempatinya. Karena setiap tempat kerja mempunyai kebijakan dan peraturan yang tidak sama dengan tempat kerja lain. Bahaya kerja yang ada juga sangat berbeda.

10. Persuasi

Penerapan berbagai metode publikasi dan imbauan untuk mengembangkan "kesadaran akan keselamatan" dapat dijadikan sebagai contoh dari persuasi. Persuasi dapat dilakukan anatar individu maupun melalui media seperti poster, spanduk, dan media lainnya.

11. Asuransi

Dapat dilakukan dengan cara penyediaan dana untuk untuk meningkatkan upaya pencegahan kecelakaan. Selain itu asuransi juga dapat digunakan untuk membantu meringankan beban korban kecelakaan karena sebagian dari biaya di tanggung asuransi.

12. Tindakan Pengamanan oleh Masing-masing Individu. 
Hal ini dilakukan dengan meningkatkan kesadaran tiap individu terhadap kesehatan dan keselamatan kerja. Peningkatan kesadaran dimulai dari diri sendiri kemudian menularkannya kepada orang lain.

Dalam penelitian ini akan dilihat faktor penyebab utama dari kejadian kecelakaan kerja yang ada di PT. XYZ. Untuk faktor penyebab yang disebabkan oleh manusia akan dibuatkan rencana pengembangan SDM untuk meningkatkan kompetensi karyawan agar dapat mengurangi kecelakaan kerja dan meningkatkan kinerja keselamatan kerja di perusahaan.

Hasil dari pelaksanaan rencana pengembangan SDM akan terlihat dari perbedaan pencapaian kinerja Key Performance Indicator (KPI) terkait keselamatan kerja yaitu dari nilai Frequency Rate (FR) dan Safe-T Score. Kedua KPI tersebut merupakan indikator dalam penilaian kinerja keselamatan kerja yang ada di perusahaan.

Frequency Rate menunjukan frekuensi angka kecelakaan dalam satu juta jam kerja untuk kurun waktu tertentu di sebuah pabrik (Parmar dkk, 2013). Hal ini dapat dilakukan dengan menghitung dengan rumus statistik kecelakaan :

Frequency Rate $=\frac{\text { Jumlah kecelakaan }}{\text { Total jam kerja } \times 1.000 .000}$

Safe-T Score menunjukan nilai indikator untuk menilai tingkat perbedaan antara dua kelompok yang dibandingkan (Parmar dkk, 2013). Apakah perbedaan pada dua kelompok tersebut bermakna atau tidak. Perbedaan ini dinilai untuk membandingkan kinerja suatu kelompok dengan kinerja sebelumnya. Hasil perbedaan ini dapat dijadikan apakah terjadi perbedaan yang mencolok atau tidak. Selanjutnya dapat dipakai untuk menilai kinerja yang telah kita lakukan. Safe-T Score dapat dihitung dengan rumus statistic kecelakaan :

Safe-T Score $=\frac{(\text { FR sekarang }- \text { FR sebelumnya })}{\sqrt{(\text { FR sebelumnya } \times 1.000 .000} / \text { Total jam kerja }}$

Score positif dari Safe T Score mengindikasikan menurunnya kinerja, sebaliknya score negatif menunjukkan peningkatan kinerja. Interpretasi dari Score ini selengkapnya sebagai berikut :

1. Safe $\mathrm{T}$ Score diantara +2.00 dan -2.00 , menunjukkan perbedaan kinerja keselamatan kerja yang ada tidak significant, atau ada sesuatu yang perlu ditingkatkan lebih lagi.

2. Safe T Score lebih besar atau sama dengan +2.00 menunjukkan menurunnya kinerja keselamatan kerja secara significant, atau ada sesuatu yang salah dan harus segera diperbaiki.

3. Safe T Score lebih kecil atau sama dengan -2.00 menunjukkan membaikknya kinerja keselamatan kerja secara significant, atau ada sesuatu yang baik dan perlu dipertahankan.

\section{HASIL, ANALISA, DAN PEMBAHASAN}

Dari data analisa internal perusahaan terkait faktor penyebab kecelakaan kerja yang terjadi pada tahun 2015 sampai 2016 diperoleh dalam tabel di bawah ini :

Tabel 1. Data kecelakaan kerja perusahaan tahun 2015 s/d 2016

\begin{tabular}{|c|l|c|c|c|c|c|c|}
\hline No. & \multicolumn{1}{|c|}{ Item } & Man & Machine & Methode & Material & Environment & Total \\
\hline 1 & $\begin{array}{l}\text { Jumlah } \\
\text { kecelakaan } \\
\text { kerja dengan } \\
\text { faktor } \\
\text { penyebab } \\
\text { (kejadian) }\end{array}$ & 44 & 7 & 24 & 3 & 3 & 81 \\
\hline 2 & $\begin{array}{l}\text { Prosentase } \\
(\%)\end{array}$ & 54.50 & 8.86 & 29.39 & 3.56 & 3.68 & 100.00 \\
\hline
\end{tabular}

Sumber: Data sekunder internal perusahaan 
Hasil analisa menunjukan bahwa 54.5\% penyebab kecelakaan kerja yang terjadi adalah faktor yang disebabkan oleh manusia/pekerja. Hal ini menunjukan bahwa perlu pengembangan dalam bidang SDM untuk mengurangi jumlah potensi kecelakaan kerja karena kesalahan manusia.

Program pengembangan SDM yang dilakukan perusahaan mengacu pada peningkatan kompetensi karyawan dan pengawasan. Peningkatan kompetensi karyawan dilakukan dengan cara pemberian pendidikan \& pelatihan sedangkan untuk pengawasan penerapan kompetensi akan dilakukan inspeksi lapangan seperti yang terdapat pada Tabel 2 dibawah. Pada masing-masing program tersebut akan dibagi berdasarkan area kerja yang ada sehingga akan mempermudah pengendalian pelaksanaan program.

Tabel 2. Program pengembangan SDM untuk mengurangi kecelakaan kerja

\begin{tabular}{|c|lc|l|}
\hline $\begin{array}{c}\text { No } \\
\cdot\end{array}$ & \multicolumn{2}{|c|}{ Objective } & \multicolumn{1}{c|}{ Program } \\
\hline 1 & $\begin{array}{l}\text { Meningkatkan } \\
\text { Karyawan }\end{array}$ & Kepedulian & Monthly Safety Monitor Inspection \\
\hline 2 & $\begin{array}{l}\text { Meningkatkan } \\
\text { karyawan }\end{array}$ & Pengetahuan & $\begin{array}{l}\text { Program Pendidikan dan Pelatihan } \\
\text { Bulanan }\end{array}$ \\
\hline
\end{tabular}

Pelaksanaan program pendidikan \& pelatihan dibagi menjadi 12 area dan berlangsung selama 1 tahun dengan masing-masing area akan mendapatkan pendidikan serta pelatihan yang berbeda-beda tiap bulannya. Materi yang diberikan merupakan pengetahuan dasar dalam pencegahan dan penanggulangan kecelakaan kerja.

Tabel 3. Program Pendidikan \& Pelatihan di Perusahaan Periode Januari s/d Juni 2017

\begin{tabular}{|c|c|c|c|c|c|c|c|}
\hline \multicolumn{8}{|c|}{ MATERI PENDIDIKAN \& PELATIHAN } \\
\hline N0 & AREA & $\mathbf{J A N}$ & FEB & MAR & APR & MAY & JUN \\
\hline 1 & Produksi & $\begin{array}{l}\text { Program } \\
\& \\
\text { Kebijaka } \\
\text { n K3 }\end{array}$ & $\begin{array}{l}\text { Pencegaha } \\
\mathrm{n} \\
\text { Kecelakaa } \\
\text { n Kerja }\end{array}$ & $\begin{array}{l}\text { Symbo } \\
1 \& \\
\text { Label } \\
\text { B3 }\end{array}$ & $\begin{array}{l}\text { Peratura } \\
\text { n K3 }\end{array}$ & $\begin{array}{l}\text { Alat } \\
\text { Proteksi } \\
\text { Kebakara } \\
\mathrm{n}\end{array}$ & $\begin{array}{l}\text { Progra } \\
\text { m 5S }\end{array}$ \\
\hline 2 & $\begin{array}{l}\text { Filling \& } \\
\text { Packaging }\end{array}$ & $\begin{array}{l}\text { Program } \\
\& \\
\text { Kebijaka } \\
\text { n K3 }\end{array}$ & $\begin{array}{l}\text { Pencegaha } \\
\mathrm{n} \\
\text { Kecelakaa } \\
\text { n Kerja }\end{array}$ & $\begin{array}{l}\text { Symbo } \\
1 \& \\
\text { Label } \\
\text { B3 }\end{array}$ & $\begin{array}{l}\text { Peratura } \\
\text { n K3 }\end{array}$ & $\begin{array}{l}\text { Alat } \\
\text { Proteksi } \\
\text { Kebakara } \\
\mathrm{n}\end{array}$ & $\begin{array}{l}\text { Progra } \\
\text { m 5S }\end{array}$ \\
\hline 3 & $\begin{array}{l}\text { Raw } \\
\text { Material } \\
\text { Warehouse }\end{array}$ & $\begin{array}{l}\text { Program } \\
\& \\
\text { Kebijaka } \\
\text { n K3 }\end{array}$ & $\begin{array}{l}\text { Pencegaha } \\
\mathrm{n} \\
\text { Kecelakaa } \\
\text { n Kerja }\end{array}$ & $\begin{array}{l}\text { Symbo } \\
1 \& \\
\text { Label } \\
\text { B3 }\end{array}$ & $\begin{array}{l}\text { Peratura } \\
\text { n K3 }\end{array}$ & $\begin{array}{l}\text { Alat } \\
\text { Proteksi } \\
\text { Kebakara } \\
\text { n }\end{array}$ & $\begin{array}{l}\text { Progra } \\
\mathrm{m} 5 \mathrm{~S}\end{array}$ \\
\hline 4 & $\begin{array}{l}\text { Finish } \\
\text { Good } \\
\text { Warehouse }\end{array}$ & $\begin{array}{l}\text { Program } \\
\& \\
\text { Kebijaka } \\
\text { n K3 }\end{array}$ & $\begin{array}{l}\text { Pencegaha } \\
\mathrm{n} \\
\text { Kecelakaa } \\
\mathrm{n} \text { Kerja }\end{array}$ & $\begin{array}{l}\text { Symbo } \\
1 \& \\
\text { Label } \\
\text { B3 }\end{array}$ & $\begin{array}{l}\text { Peratura } \\
\text { n K3 }\end{array}$ & $\begin{array}{l}\text { Alat } \\
\text { Proteksi } \\
\text { Kebakara } \\
\text { n }\end{array}$ & $\begin{array}{l}\text { Progra } \\
\mathrm{m} 5 \mathrm{~S}\end{array}$ \\
\hline
\end{tabular}


Jurnal Inkofar * Volume 1 No. 1, Juli 2018 * ISSN: 2615-3645 (Print) / 2581-2920 (Online)

Tersedia secara online di: http://www.politeknikmeta.ac.id/meta/ojs/

\begin{tabular}{|c|c|c|c|c|c|c|c|}
\hline 6 & $\mathrm{R} \& \mathrm{D}$ & $\begin{array}{l}\text { Program } \\
\& \\
\text { Kebijaka } \\
\text { n K3 }\end{array}$ & $\begin{array}{l}\text { Pencegaha } \\
\mathrm{n} \\
\text { Kecelakaa } \\
\text { n Kerja }\end{array}$ & $\begin{array}{l}\text { Symbo } \\
1 \& \\
\text { Label } \\
\text { B3 }\end{array}$ & $\begin{array}{l}\text { Peratura } \\
\text { n K3 }\end{array}$ & $\begin{array}{l}\text { Alat } \\
\text { Proteksi } \\
\text { Kebakara } \\
\text { n }\end{array}$ & $\begin{array}{l}\text { Progra } \\
\mathrm{m} 5 \mathrm{~S}\end{array}$ \\
\hline 7 & $\begin{array}{l}\text { Customer } \\
\text { Sample }\end{array}$ & $\begin{array}{l}\text { Program } \\
\& \\
\text { Kebijaka } \\
\text { n K3 }\end{array}$ & $\begin{array}{l}\text { Pencegaha } \\
\text { n } \\
\text { Kecelakaa } \\
\text { n Kerja }\end{array}$ & $\begin{array}{l}\text { Symbo } \\
1 \& \\
\text { Label } \\
\text { B3 }\end{array}$ & $\begin{array}{l}\text { Peratura } \\
\text { n K3 }\end{array}$ & $\begin{array}{l}\text { Alat } \\
\text { Proteksi } \\
\text { Kebakara } \\
\text { n }\end{array}$ & $\begin{array}{l}\text { Progra } \\
\mathrm{m} 5 \mathrm{~S}\end{array}$ \\
\hline 8 & $\begin{array}{l}\text { Maintenanc } \\
\mathrm{e}\end{array}$ & $\begin{array}{l}\text { Program } \\
\& \\
\text { Kebijaka } \\
\text { n K3 }\end{array}$ & $\begin{array}{l}\text { Pencegaha } \\
\mathrm{n} \\
\text { Kecelakaa } \\
\mathrm{n} \text { Kerja }\end{array}$ & $\begin{array}{l}\text { Symbo } \\
1 \& \\
\text { Label } \\
\text { B3 }\end{array}$ & $\begin{array}{l}\text { Peratura } \\
\text { n K3 }\end{array}$ & $\begin{array}{l}\text { Alat } \\
\text { Proteksi } \\
\text { Kebakara } \\
\mathrm{n}\end{array}$ & $\begin{array}{l}\text { Progra } \\
\mathrm{m} 5 \mathrm{~S}\end{array}$ \\
\hline 9 & $\begin{array}{l}\text { All Office } \\
\text { \& General } \\
\text { Affair }\end{array}$ & $\begin{array}{l}\text { Program } \\
\& \\
\text { Kebijaka } \\
\text { n K3 }\end{array}$ & $\begin{array}{l}\text { Pencegaha } \\
\mathrm{n} \\
\text { Kecelakaa } \\
\mathrm{n} \text { Kerja }\end{array}$ & $\begin{array}{l}\text { Symbo } \\
1 \& \\
\text { Label } \\
\text { B3 }\end{array}$ & $\begin{array}{l}\text { Peratura } \\
\text { n K3 }\end{array}$ & $\begin{array}{l}\text { Alat } \\
\text { Proteksi } \\
\text { Kebakara } \\
\text { n }\end{array}$ & $\begin{array}{l}\text { Progra } \\
\mathrm{m} 5 \mathrm{~S}\end{array}$ \\
\hline 10 & Distribution & $\begin{array}{l}\text { Program } \\
\& \\
\text { Kebijaka } \\
\text { n K3 }\end{array}$ & $\begin{array}{l}\text { Pencegaha } \\
\mathrm{n} \\
\text { Kecelakaa } \\
\text { n Kerja }\end{array}$ & $\begin{array}{l}\text { Symbo } \\
1 \& \\
\text { Label } \\
\text { B3 }\end{array}$ & $\begin{array}{l}\text { Peratura } \\
\text { n K3 }\end{array}$ & $\begin{array}{l}\text { Alat } \\
\text { Proteksi } \\
\text { Kebakara } \\
\text { n }\end{array}$ & $\begin{array}{l}\text { Progra } \\
\mathrm{m} 5 \mathrm{~S}\end{array}$ \\
\hline
\end{tabular}

Tabel 4. Program Pendidikan \& Pelatihan di Perusahaan Periode Juli s/d Desember 2017

\begin{tabular}{|c|c|c|c|c|c|c|c|}
\hline \multicolumn{8}{|c|}{ MATERI PENDIDIKAN \& PELATIHAN } \\
\hline $\begin{array}{c}\text { No } \\
\text {. }\end{array}$ & AREA & JUL & AUG & SEP & OCT & NOV & DEC \\
\hline 1 & Prod & $\begin{array}{l}\text { Kondisi } \\
\text { Darurat }\end{array}$ & $\begin{array}{l}\text { Handlin } \\
\text { g B3 }\end{array}$ & $\begin{array}{l}\text { Handlin } \\
\text { g } \\
\text { Limbah } \\
\text { B3 }\end{array}$ & $\begin{array}{l}\text { Tumpah } \\
\text { an B3 }\end{array}$ & $\begin{array}{l}\text { Kondisi } \\
\text { Kebakar } \\
\text { an }\end{array}$ & $\begin{array}{l}\text { APD di } \\
\text { Area } \\
\text { Kerja }\end{array}$ \\
\hline 2 & $\begin{array}{l}\text { Filling \& } \\
\text { Packaging }\end{array}$ & $\begin{array}{l}\text { Kondisi } \\
\text { Darurat }\end{array}$ & $\begin{array}{l}\text { Handlin } \\
\text { g B3 }\end{array}$ & $\begin{array}{l}\text { Handlin } \\
\text { g } \\
\text { Limbah } \\
\text { B3 }\end{array}$ & $\begin{array}{l}\text { Tumpah } \\
\text { an B3 }\end{array}$ & $\begin{array}{l}\text { Kondisi } \\
\text { Kebakar } \\
\text { an }\end{array}$ & $\begin{array}{l}\text { APD di } \\
\text { Area } \\
\text { Kerja }\end{array}$ \\
\hline 3 & $\begin{array}{l}\text { Raw } \\
\text { Material } \\
\text { Warehous } \\
\text { e }\end{array}$ & $\begin{array}{l}\text { Kondisi } \\
\text { Darurat }\end{array}$ & $\begin{array}{l}\text { Handlin } \\
\text { g B3 }\end{array}$ & $\begin{array}{l}\text { Handlin } \\
\text { g } \\
\text { Limbah } \\
\text { B3 }\end{array}$ & $\begin{array}{l}\text { Tumpah } \\
\text { an B3 }\end{array}$ & $\begin{array}{l}\text { Kondisi } \\
\text { Kebakar } \\
\text { an }\end{array}$ & $\begin{array}{l}\text { APD di } \\
\text { Area } \\
\text { Kerja }\end{array}$ \\
\hline 4 & $\begin{array}{l}\text { Finish } \\
\text { Good } \\
\text { Warehous } \\
\text { e }\end{array}$ & $\begin{array}{l}\text { Kondisi } \\
\text { Darurat }\end{array}$ & $\begin{array}{l}\text { Handlin } \\
\text { g B3 }\end{array}$ & $\begin{array}{l}\text { Handlin } \\
\text { g } \\
\text { Limbah } \\
\text { B3 }\end{array}$ & $\begin{array}{l}\text { Tumpah } \\
\text { an B3 }\end{array}$ & $\begin{array}{l}\text { Kondisi } \\
\text { Kebakar } \\
\text { an }\end{array}$ & $\begin{array}{l}\text { APD di } \\
\text { Area } \\
\text { Kerja }\end{array}$ \\
\hline 6 & $\mathrm{R} \& \mathrm{D}$ & $\begin{array}{l}\text { Kondisi } \\
\text { Darurat }\end{array}$ & $\begin{array}{l}\text { Handlin } \\
\text { g B3 }\end{array}$ & $\begin{array}{l}\text { Handlin } \\
\text { g } \\
\text { Limbah } \\
\text { B3 }\end{array}$ & $\begin{array}{l}\text { Tumpah } \\
\text { an B3 }\end{array}$ & $\begin{array}{l}\text { Kondisi } \\
\text { Kebakar } \\
\text { an }\end{array}$ & $\begin{array}{l}\text { APD di } \\
\text { Area } \\
\text { Kerja }\end{array}$ \\
\hline 7 & $\begin{array}{l}\text { Customer } \\
\text { Sample }\end{array}$ & $\begin{array}{l}\text { Kondisi } \\
\text { Darurat }\end{array}$ & $\begin{array}{l}\text { Handlin } \\
\text { g B3 }\end{array}$ & $\begin{array}{l}\text { Handlin } \\
\mathrm{g} \\
\text { Limbah }\end{array}$ & $\begin{array}{l}\text { Tumpah } \\
\text { an B3 }\end{array}$ & $\begin{array}{l}\text { Kondisi } \\
\text { Kebakar } \\
\text { an }\end{array}$ & $\begin{array}{l}\text { APD di } \\
\text { Area } \\
\text { Kerja }\end{array}$ \\
\hline
\end{tabular}




\begin{tabular}{|c|c|c|c|c|c|c|c|}
\hline & & & & B3 & & & \\
\hline 8 & $\begin{array}{l}\text { Maintenan } \\
\text { ce }\end{array}$ & $\begin{array}{l}\text { Kondisi } \\
\text { Darurat }\end{array}$ & $\begin{array}{l}\text { Handlin } \\
\text { g B3 }\end{array}$ & $\begin{array}{l}\text { Handlin } \\
\text { g } \\
\text { Limbah } \\
\text { B3 }\end{array}$ & $\begin{array}{l}\text { Tumpah } \\
\text { an B3 }\end{array}$ & $\begin{array}{l}\text { Kondisi } \\
\text { Kebakar } \\
\text { an }\end{array}$ & $\begin{array}{l}\text { APD di } \\
\text { Area } \\
\text { Kerja }\end{array}$ \\
\hline 9 & $\begin{array}{l}\text { All Office } \\
\text { \& General } \\
\text { Affair }\end{array}$ & $\begin{array}{l}\text { Kondisi } \\
\text { Darurat }\end{array}$ & $\begin{array}{l}\text { Handlin } \\
\text { g B3 }\end{array}$ & $\begin{array}{l}\text { Handlin } \\
\text { g } \\
\text { Limbah } \\
\text { B3 }\end{array}$ & $\begin{array}{l}\text { Tumpah } \\
\text { an B3 }\end{array}$ & $\begin{array}{l}\text { Kondisi } \\
\text { Kebakar } \\
\text { an }\end{array}$ & $\begin{array}{l}\text { APD di } \\
\text { Area } \\
\text { Kerja }\end{array}$ \\
\hline 10 & $\begin{array}{l}\text { Distributi } \\
\text { on }\end{array}$ & $\begin{array}{l}\text { Kondisi } \\
\text { Darurat }\end{array}$ & $\begin{array}{l}\text { Handlin } \\
\text { g B3 }\end{array}$ & $\begin{array}{l}\text { Handlin } \\
\text { g } \\
\text { Limbah } \\
\text { B3 }\end{array}$ & $\begin{array}{l}\text { Tumpah } \\
\text { an B3 }\end{array}$ & $\begin{array}{l}\text { Kondisi } \\
\text { Kebakar } \\
\text { an }\end{array}$ & $\begin{array}{l}\text { APD di } \\
\text { Area } \\
\text { Kerja }\end{array}$ \\
\hline
\end{tabular}

Pelaksanaan inspeksi akan mengikuti pembagian area kerja yang ada. Inspeksi akan dilaksanakan di akhir bulan secara berkala untuk melihat penerapan kompetensi yang telah diberikan pada program pendidikan dan pelatihan seperti pada table 5 .

Tim inspeksi adalah perwakilan dari area kerja yang berjumlah 2 orang seperti pada tabel 6. Tim inspeksi ini akan melakukan inspeksi di area lain secara bergantian disetiap bulannya. Temuan dari tim inspeksi akan menjadi bahan evaluasi dari tim pendidikan \& pelatihan untuk masing-masing area dan pekerja.

Tabel 5. Jadwal Inspeksi di Perusahan Periode Januari s/d Desember 2017 JADWAL INSPEKSI MENDADAK (SIDAK)

\begin{tabular}{|c|c|c|c|c|c|c|c|c|c|c|c|c|c|}
\hline \multicolumn{14}{|c|}{ JADWAL INSPEKSI MENDADAK (SIDAK) } \\
\hline NO & AREA & $\begin{array}{l}\vec{Z} \\
\frac{2}{Z}\end{array}$ & 国 & $\frac{2}{2}$ & $\frac{D}{d}$ & $\frac{3}{2}$ & $\ddot{Z}$ & - & $\stackrel{D}{\Omega}$ & $\underset{\sigma}{\sigma}$ & $\stackrel{8}{\Omega}$ & $\begin{array}{l}z \\
0 \\
2\end{array}$ & 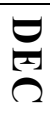 \\
\hline 1 & Produksi & $\mathrm{B}$ & $\mathrm{C}$ & $\mathrm{D}$ & $\mathrm{E}$ & $\mathrm{F}$ & G & $\mathrm{H}$ & I & $\mathrm{B}$ & $\mathrm{C}$ & $\mathrm{D}$ & $\mathrm{E}$ \\
\hline 2 & $\begin{array}{l}\text { Filling \& } \\
\text { Packaging }\end{array}$ & $\mathrm{C}$ & D & $\mathrm{E}$ & $\mathrm{F}$ & $\mathrm{G}$ & $\mathrm{H}$ & I & A & $\mathrm{C}$ & D & $\mathrm{E}$ & $\mathrm{F}$ \\
\hline 3 & $\begin{array}{c}\text { Raw } \\
\text { Material } \\
\text { Warehouse }\end{array}$ & $\mathrm{D}$ & $\mathrm{E}$ & $\mathrm{F}$ & $\mathrm{G}$ & $\mathrm{H}$ & I & A & B & D & $\mathrm{E}$ & $\mathrm{F}$ & $\mathrm{G}$ \\
\hline 4 & $\begin{array}{c}\text { Finish } \\
\text { Good } \\
\text { Warehouse }\end{array}$ & $\mathrm{E}$ & $\mathrm{F}$ & $\mathrm{G}$ & $\mathrm{H}$ & I & A & B & $\mathrm{C}$ & $\mathrm{E}$ & $\mathrm{F}$ & $\mathrm{G}$ & $\mathrm{H}$ \\
\hline 6 & $\mathrm{R} \& \mathrm{D}$ & $\mathrm{F}$ & G & $\mathrm{H}$ & $\mathrm{I}$ & A & B & $\mathrm{C}$ & $\mathrm{D}$ & $\mathrm{F}$ & $\mathrm{G}$ & $\mathrm{H}$ & I \\
\hline 7 & $\begin{array}{l}\text { Customer } \\
\text { Sample }\end{array}$ & $\mathrm{G}$ & $\mathrm{H}$ & I & A & B & $\mathrm{C}$ & D & $\mathrm{E}$ & $\mathrm{G}$ & $\mathrm{H}$ & I & $\mathrm{A}$ \\
\hline 8 & $\begin{array}{c}\text { Maintenan } \\
\text { ce }\end{array}$ & $\mathrm{H}$ & I & A & B & $\mathrm{C}$ & D & $\mathrm{E}$ & $\mathrm{F}$ & $\mathrm{H}$ & I & A & B \\
\hline 9 & $\begin{array}{l}\text { All Office } \\
\& \text { General }\end{array}$ & I & A & B & $\mathrm{C}$ & D & $\mathrm{E}$ & $\mathrm{F}$ & $\mathrm{G}$ & I & A & B & $\mathrm{C}$ \\
\hline
\end{tabular}




\begin{tabular}{|c|c|c|c|c|c|c|c|c|c|c|c|c|c|}
\hline & Affair & & & & & & & & & & & & \\
\hline 10 & $\begin{array}{c}\text { Distributio } \\
\mathrm{n}\end{array}$ & A & B & C & D & E & F & G & H & A & B & C & D \\
\hline
\end{tabular}

Tabel 6. Jadwal Perwakilan Team Inspeksi

\begin{tabular}{|c|l|c|}
\hline \multicolumn{2}{|c|}{ PERWAKILAN AUDITOR SIDAK } \\
\hline NO. & \multicolumn{1}{|c|}{ AREA } & INISIAL \\
\hline 1 & Produksi & A \\
\hline 2 & Filling \& Packaging & B \\
\hline 3 & $\begin{array}{l}\text { Raw } \\
\text { Warehouse }\end{array}$ & C \\
\hline 4 & Finish Good Warehouse & D \\
\hline 6 & R \& D & E \\
\hline 7 & Customer Sample & F \\
\hline 8 & Maintenance & G \\
\hline 9 & $\begin{array}{l}\text { All Office \& General } \\
\text { Affair }\end{array}$ & H \\
\hline 10 & Distribution & I \\
\hline
\end{tabular}

Data pada tabel 7 merupakan data yang akan digunakan dalam membandingkan kinerja keselamatan kerja pada periode 2015-2016 sebelum dilakukan program pengembangan SDM terkait keselamatan kerja dengan periode 2017 setelah pelaksanaan program.

Tabel 7. Data \& KPI Keselamatan Kerja Perusahaan

\begin{tabular}{|c|c|c|c|c|}
\hline No. & Item & Tahun & Total & Satuan \\
\hline 1 & \multirow{4}{*}{ Jam Kerja } & 2015 & $2,494,033.19$ & \multirow{4}{*}{ jam } \\
\hline 2 & & 2016 & $2,318,388.49$ & \\
\hline 3 & & $2015 \mathrm{~s} / \mathrm{d} 2016$ & $4,812,421.68$ & \\
\hline 4 & & 2017 & $2,204,969.24$ & \\
\hline 5 & \multirow{4}{*}{$\begin{array}{c}\text { Kecelakaan } \\
\text { Kerja }\end{array}$} & 2015 & 6.00 & \multirow{4}{*}{ kasus } \\
\hline 6 & & 2016 & 5.00 & \\
\hline 7 & & $2015 \mathrm{~s} / \mathrm{d} 2016$ & 11.00 & \\
\hline 8 & & 2017 & 2.00 & \\
\hline 9 & \multirow{2}{*}{ FR } & $2015 \mathrm{~s} / \mathrm{d} 2016$ & 2.29 & \\
\hline 10 & & 2017 & 0.91 & \\
\hline 11 & Safe-T Score & $\begin{array}{c}2017 \\
\text { dibandingkan } \\
2015 \mathrm{~s} / \mathrm{d} 2016\end{array}$ & -1.35 & \\
\hline
\end{tabular}

Sumber : Data sekunder internal perusahaan

Data jumlah jam kerja dan kecelakaan kerja dievaluasi dengan menggunakan KPI FR sehingga dapat diketahui nilai potensi kejadian kecelakaan kerja. Pada periode 2015-2016 berdasarkan perhitungan diketahui memiliki nilai FR sebesar 2.29 yang 
artinya pada periode tersebut potensi terjadinya kecelakaan kerja sebesar 2.29 kali kecelakaan kerja untuk setiap 1.000 .000 jam kerja. Pada periode 2017berdasarkan perhitungan diketahui memiliki nilai FR sebesar 0.91 yang artinya pada tahun 2017 potensi terjadinya kecelakaan kerja sebesar 0.91 kali kejadian kecelakaan kerja untuk setiap 1.000.000 jam kerja.

Nilai FR 2017 mengalami penurunan dibandingkan nilai FR periode 2015-2016 hal ini menunjukan bahwa potensi terjadinya kecelakaan kerja telah mengalami penurunan dari 2.29 kali menjadi 0.91 kali. Dari hasil perhitungan diperoleh nilai Safet-T Score sebesar -1.35 yang artinya bahwa telah terjadi peningkatan kinerja keselamatan kerja meskipun belum optimal karena nilainya masih diatas -2 .

\section{KESIMPULAN}

Program pengembangan SDM merupakan salah satu cara dalam mengurangi potensi kecelakaan kerja yang disebabkan oleh kesalahan manusia. Kesalahan manusia sering terjadi karena kurangnya pengetahuan pada potensi bahaya pekerjaannya. Program pendidikan \& pelatihan diharapkan dapat meningkatkan pengetahuan dasar yang dibutuhkan pekerja dalam menganalisa potensi bahaya sehingga dapat meminimalisasi potensi kecelakaan kerja. Pengawasan dalam konsistensi pelaksanaan pendidikan \& pelatihan menjadi salah satu kunci pengembangan SDM agar dapat memastikan bahwa setiap pekerja melaksanakan pekerjaannya sesuai dengan pendidikan \& pelatihan yang telah diberikan.

Hasil penerapan program tersebut adalah penurunan nilai KPI FR dari 2.29 pada periode 2015-2016 menjadi 0.91 pada periode 2017, hal ini menunjukan bahwa potensi terjadinya kecelakaan kerja semakin kecil. Pada KPI Safe-T Score diperoleh nilai -1.35 hal ini menunjukan telah terjadi perubahan kinerja perusahaan terkait keselamatan kerja namun belum secara significant sehingga masih perlu programprogram lainnya untuk meningkatkan kinerja perusahaan kedepannya.

\section{DAFTAR PUSTAKA}

Ahmad, Tohardi. 2008. Pemahaman Praktis Manajemen Sumber Daya Manusia. Bandung: Universitas Tanjung Pura, Mandar Maju.

Anton, Thomas J. (1989). Occupational safety and health management.Singapore: McGrawHill Book.Co.

Hasibuan, M. Manajemen Sumber daya Manusia, 2008. Bumi Aksara, Jakarta.

ILO. 1989. Encylopedia of Occupational Health and Safety : Geneva.

Nadler, L. (1990). Pengembangan Sumber Daya Manusia. Erlangga, Jakarta.

Parmar, V., Choukse, R.M. \& Patel, P. (2013). Safety Performance Monitoring in Pump Manufacturing Industries. International Journal of Engineering Research \& Technology (IJERT).

Peraturan Pemerintah Nomor 50 Tahun 2012 tentang Sistem Manajemen keselamatan dan Kesehatan Kerja (SMK3). 